Internal fats were very developped at each stage, but subsutaneous adipose tissues were scarce and sternal (ST) tissue was the only dissectable subcutancous fat. Great omentum (GO) was always the heaviest. Its weight was 2750 (C.V. 42 p. 100), 2570 (C.V. 31 p. 100), 2540 (C.V. 81 p. 100), 2650 g (C.V. 40 p. 100) respectively for $W-7, W-3$, $w+3, w+4, w+36$ slaughtered goats. It represented about $45 \mathrm{p} .100$ of the internal fats. Perirenal (PR), mesenteric (MES), minus omentum (MO) and pericardic (PC) adipose tissues weights represented only about $25,20,4$ and $3 \mathrm{p}$. 100 of internal fats.

Sternal fat, by contrast was very low, about $150 \mathrm{~g}$ with a medium C.V. of $50 \mathrm{p} .100$ for each stage.

The correlation coefficients between the different adipose tissue weights were high $(\mathrm{r}>0.8)$ at $\mathrm{W}-7$ before parturition, then decreased around parturition for $\mathrm{W}-3$ and $W+2$ slaughtered goats and afterwards slowly increased up to 36 weeks of lactation. Two weeks after parturition, sternal weight semed to have a very weak correlation with others ( $r=0.33$ between $\mathrm{ST}$ and GO for $\mathrm{W}+2$ goats).

GO and PR tissues had a lower water content than the other adipose tissues. As for the other internal fats, water content rose after parturition. Its average value at the three stages : $\mathrm{W}+36, \mathrm{~W}-7$ and $\mathrm{W}-3$ were $5.5,5.1,8.9,12.0,7.9,22.5$ p. 100 respectively for GO, PR, MES, PC, MO and ST. But the average water content of these tissues at $\mathrm{W}+2$ and $W+4$ was respectively $12,10.1,19.6,13.6,8.5,14.3$ p. 100 .

Lipoprotein lipase activity expressed per $\mathrm{g}$ of wet tissue was higher in internal fat than in sternal tissue. Despite the low number of animals slaughtered at each stage and the wide variability between animals, it seemed clear that LPL activity was lower in late pregnancy. For great omentum, its activity was $61,13,78,18$ and $102 \mathrm{~nm} / \mathrm{mn}^{-1} / \mathrm{g}^{-1}$ (C.V. $=76,63,82,97$ and 83 p. 100) respectively for $W-7, W-3, W+2, W+4$, $\mathrm{W}+36$ slaughtered goats.

The variability between fat depot weights was wider than between stages of the reproductive cycle. Water and lipid contents which showed a water content variation between these stages seemed to be good indicators of lipolysis status particularly for great omentum and for perirenal adipose tissue. Minus omentum and sternal adipose tissue appeared to have a lower rate of lipolysis and lipogenesis than the others.

Key words : Goat, adipose tissue, pregnancy, lactation, lipoprotein lipase, fat content.

\title{
Selenium - Vitamin E in the nutrition of the Saanen kid
}

\author{
J. KESSLER, D. GUBLER, M. WANNER
}

Swiss Federal Research Station for Animal Production

Grangeneuve, $\mathrm{CH}-1725$ Posieux

Kids are dependent on an adequate intra- and extrauterine selenium supply, like livestock in general. Reduced growth and degeneration of the heart- and skeletal muscle (white muscle disease) are the main symptoms of an inadequate selenium - vitamin E supply.

By means of a single intramuscular injection of $5 \mathrm{ml}$ Injacom E-selenium (1) in the dam four weeks before the expected parturition time and/or by treating the young animal with $2 \mathrm{ml}$ Injacom E-selenium at the end of the 2 nd week of life the often insufficient supply in the kids with these micronutrients can be improved. This is shown by the development of the Seand vitamin E-content of the blood and by the activity of the Se-dependent GlutathionePeroxidase (GSH-Px) in the erythrocytes. At the age of 3, 4, 6, 8 and 10 weeks the measured

(1) Injacom E-selenium (Hoffmann-La Roche \& Co.) : Hydrous solution with $150 \mathrm{mg}$ vitamin E-acetate and $1.67 \mathrm{mg}$ sodium selenite-pentahydrate per $\mathrm{ml}$. 
activity of the GSH-Px of all treated kids of untreated and treated dams was $177,245,240$, 150 and $143 \mathrm{U} / \mathrm{g}$ respectively for Hemoglobin $(\mathrm{Hb})$. The comparable values of the untreated kids of untreated and treated dams were $39,55,91,68$ and $78 \mathrm{U} / \mathrm{g}$ respectively for $\mathrm{Hb}$. The observed difference was significant $(\mathrm{P}<5 \mathrm{p} .100)$.

Compared to the dam treatment, the kid treatment seems to have a stronger influence both on the Se- and vitamin E supply.

When selenium was administered to the kids orally one day after birth in the form of drenches (same time and same quantity as by injection), a slightly lower effect ( $P>5$ p. 100) was observed as shown by the GSH-Px activity. From the first to the fourth week of life this activity up from $18 \mathrm{U} / \mathrm{g}$ to $91 \mathrm{U} / \mathrm{g} \mathrm{Hb}$ in the injection group. When selenium was administered in the form of drenches, the corresponding values were $22 \mathrm{U} / \mathrm{g}$ and $84 \mathrm{U} / \mathrm{g} \mathrm{Hb}$, resp.

Key words : Selenium, vitamin E, goat, kid, supplementation, parenteral, oral.

\title{
The use of milk replacers based on soya protein and whey for kid
}

\author{
A. MOWLEM \\ Animal and Grassland Research Institute, Shinfield, Reading, RG2 9AQ, England
}

A wide range of milk replacers are available for rearing calves and few specifically for goat kids. The performance, in terms of growth rate, was recorded for two groups of goat kids reared on two commercially available milk replacers based on skim milk and on soya protein and whey. This was offered via a multi-teat self feeder and the kids were weaned at 6 weeks.

The two milk substitutes used were Denkwik made up from a minimum of 62 p. 100 skim milk with tallow and coconut oil to give an analysis of 16 p. 100 fat and 26 p. 100 crude protein and Speen-Foc made up from 10 p. 100 alcohol treated soya protein with whey, whey protein concentrate, tallow and coconut oil. Both were manufactured by British Denkavit, Poole, England. From 2 weeks of age the kids had ad libitum access to grass hay, a calf weaner pencil (16 p. $100 \mathrm{CP}$ BOCM, Basingstoke, England) and clean water.

A difference in growth rate $(P<0.05)$ in favour of the soya-whey replacer group was recorded. Between weeks 1-10 the soya-whey group gained $14.4 \mathrm{~kg}$ compared with $12.6 \mathrm{~kg}$ for the skim milk replacer group. No evidence of allergenicity of soya protein was seen, the only cases of diarthoea recorded were directly attributable to coccidiosis where some animals from each group were affected. Later comparison at +18 weeks of age showed no significant difference and it was concluded that for early weaning, at least, the choice of milk replacer is not so important in terms of growth performance and it is likely that economic factors will therefore influence the choice of feed. At the time of writing the UK price for the skim based product is $£ 770$ /tonne, the soya-whey product $£ 650$ /tonne and goat milk in terms of dry matter has a wholesale value of $£ 3000$ /tonne. When related to cost of rearing a kid to a weaning age of 6 weeks, this would require $£ 8.5$ of skim milk replacer, $£ 7$ for the soya-whey product or $£ 27$ for an equivalent quantity of goat milk.

Key words : Goat, milk-replacer, soya protein, rearing, whey. 